\title{
LITERATURE REVIEW : PENERAPAN LATIHAN KEMAMPUAN POSITIF TERHADAP PENINGKATAN HARGA DIRI RENDAH PADA KLIEN YANG MENGALAMI SKIZOFRENIA
}

\author{
Bayu Seto Rindi Atmojoํㅜ, Mustika Ayu Purbaningrum²
}

\author{
Akademi Keperawatan Pemkab Purworejo \\ Purworejo, (0275)3140576 \\ Email: bayuatmojo97@gmail.com
}

\begin{abstract}
ABSTRAK
Latar Belakang : Kemampuan positif merupakan kemampuan atau aspek positif yang dimiliki individu untuk mengidentifikasi kemampuan yang ada pada diri individu itu sendiri, sehingga klien dapat memilih kegiatan sesuai kemampuan yang dimilikinya. Pada pasien dengan harga diri rendah itu memandang kalau dirinya itu tidak berguna dan merasa dirinya tidak mampu, dengan cara melatih kemampuan positif dapat menggali aspek-aspek kemampuan positif yang dimilikinya sehingga diharapkan klien mampu memandang dirinya itu berguna dan menjadi individu yang baik. Tujuan: Untuk mengetahui penerapan latihan kemampuan positif dalam membantu mengatasi masalah harga diri rendah pada pasien gangguan jiwa. Metode: Literatur review ini menggunakan kriteria inklusi dan eksklusi, Studi ini diperoleh dan dicari secara elektronik dengan database yaitu google cendekia (20152020). Strategi pencarian yang dilakukan distilah yang di gunakan dalam bahasa inggris adalah sebagai berikut: "skizofrenia", "harga diri rendah", "Latihan kemampuan positif". Hasil: hasil literatur review dari 5 artikel menunjukkan bahwa latihan kemampuan positif sangat bervariasi. Latihan kemampuan positif dimaksud terdiri dari aktivitas merias diri, terapi menjahit, aktivitas mencuci, kegiatan menggambar dan kegiatan Plant Therapy. Secara signifikan menunjukkan semua latihan kemampuan positif dapat meningkatkan dan mempertahankan kemampuan yang masih dimiliki klien. Kesimpulan: Latihan kemampuan positif dapat digunakan untuk mengatasi masalah keperawatan pada klien yang mengalami skizofrenia dengan gangguan konsep diri harga diri rendah.
\end{abstract}

Kata kunci : Skizofrenia, Harga Diri Rendah, Latihan Kemampuan positif

\begin{abstract}
Background: Positive ability is the ability or positive aspect of an individual to identify the ability that exists in the individual itself, so that clients can choose activities according to their abilities. In patients with low self-esteem, they see that they are not useful and feel they are not able to, by practicing positive abilities, they can explore aspects of their positive abilities so that they are expected to be able to see themselves useful and become good individuals.Objective: To determine the application of positive ability exercises in helping to overcome the problem of low self-esteem in patients with mental disorders. Method: The study used in this study was a literature review of positive ability exercises. Searching for the article is done by Google Scholar or Google Scholar, published from 2015 to 2020 which is accessed fulltext in PDF format. Of the 5 studies used 3 of them used the case study method, 1 the other used the Quasi Experimental Pre-post without control method and 1 the other used the lecture and discussion method. Results: Literature review shows that positive ability exercises vary greatly. The positive skills training consists of self-dressing activities, sewing therapy, washing activities, drawing activities and Plant Therapy activities. Significantly shows that all positive ability exercises can enhance and maintain the abilities that the client still has. Conclusion: Positive ability
\end{abstract}


training can be used to overcome nursing problems in patients with schizophrenia with impaired selfconcept of low self-esteem.

\section{Keyword: Schizophrenia, Low Self-Esteem, Positive Abilities Exercise}

\section{Latar Belakang}

Skizofrenia adalah suatu gangguan mampu, dengan cara melatih kemampuan positif dapat menggali aspek-aspek kemampuan positif yang dimilikinya sehingga diharapkan klien mampu memandang dirinya itu berguna dan menjadi individu yang baik. Menurut penelitian yang dilakukan (Supriyono, 2016) dalam 6 kali pertemuan klien dapat membina hubungan saling percaya, klien dapat melaksanakan perawatan diri dengan bantuan perawat, klien dapat melaksanakan perawatan diri secara mandiri psikiatrik yang memiliki tanda dan gejala diorganisasi pola pikir, masalah pada komunikasi dan kognisi, dan gangguan persepsi terutama halusinasi dan waham. Gejala-gejala lain dari skizofrenia antara lain mengabaikan penampilan pada dirinya, cenderung menarik diri dari lingkungan sosial, berkurangnya motivasi diri dan timbulnya rasa tidak nyaman (Yuniar, 2017).

Harga diri rendah adalah perasaan negatif terhadap dirinya sendiri menyebabkan kehilangan rasa percaya diri, pesimis, dan tidak berharga di kehidupan. Harga Diri yang tinggi dikaitkan dengan anxiety yang rendah, efektif dalam kelompok dan penerimaan orang lain terhadap dirinya, sedangkan masalah keperawatan dapat menyebabkan harga diri rendah, sehingga harga diri rendah dikaitkan dengan hubungan interpersonal yang buruk dan berisiko terjadinya depresi dan skizofrenia, sehingga perasaan negatif mendasari hilangnya kepercayaan diri dan harga diri individu dan gangguan harga diri (Muhith, 2016).

Prevalensi gangguan jiwa berat di Indonesia sebesar 1,7 per mil. Prevalensi gangguan jiwa berat berdasarkan tempat tinggal dan kuintil indeks kepemilikan dipaparkan pada buku Riskesdas 2013 dalam Angka. Angka prevalensi seumur hidup skizofrenia di dunia bervariasi berkisar 4 permil sampai dengan 1,4 persen.

Beberapa kepustakaan menyebutkan secara umum prevalensi skizofrenia sebesar 1 persen penduduk. Prevalensi psikosis tertinggi di DI Yogyakarta dan Aceh (masing-masing $2,7 \%$ ), sedangkan yang terendah di Kalimantan Barat $(0,7 \%)$ dengan responden gangguan jiwa berat berdasarkan data Riskesdas 2013 adalah sebanyak 1.728 orang (Badan Penelitian dan Pengembangan Kesehatan, 2013).

Prevalensi gangguan jiwa di Provinsi Jawa Tengah tahun 2013 sebanyak 317.504. Sebagian besar kunjungan gangguan jiwa adalah di rumah sakit sebanyak $60.59 \%$ (Dinas Kesehatan Provinsi Jawa Tengah, 2015). Dampak dari tingginya gangguan jiwa menyebabkan peran sosial yang terhambat dan menimbulkan penderitaan pada klien karena perilaku yang buruk. Dengan meningkatkan pelaksaan pengawasan dan evaluasi program kegiatan kesehatan jiwa dengan cara peningkatan pembinaan program kegiatan 
kesehatan jiwa di sarana kesehatan pemerintah, swasta da an puskesmas terutama upaya promotif dan preventif.

Kemampuan positif merupakan kemampuan atau aspek positif yang dimiliki individu untuk mengidentifikasi kemampuan yang ada pada diri individu itu sendiri, sehingga klien dapat memilih kegiatan sesuai kemampuan yang dimilikinya.

Pada pasien dengan harga diri rendah itu memandang kalau dirinya itu tidak berguna dan merasa dirinya tidak mampu, dengan cara melatih kemampuan positif dapat menggali aspek-aspek kemampuan positif yang dimilikinya sehingga diharapkan klien mampu memandang dirinya itu berguna dan menjadi individu yang baik. Menurut penelitian yang dilakukan (Supriyono, 2016) dalam 6 kali pertemuan klien dapat membina hubungan saling percaya, klien dapat melaksanakan perawatan diri dengan bantuan perawat, klien dapat melaksanakan perawatan diri secara mandiri.

\section{Metode Penelitian}

Metode yang digunakan dalam literature review ini menggunakan desain Quasi Eksperimen dan studi kasus. Tipe studi yang direview adalah semua jenis penelitian yang menggunakan penerapan latihan kemampuan positif dalam meningkatkan rasa percaya diri pada klien dengan harga diri rendah. Literature review ini disusun melalui penelusuran artikel penelitian yang terpublikasi. Penelusuran jurnal dilakukan dengan pendekatan data (database) seperti Google Scholar atau Google Cendekia dengan menggunakan kata kunci seperti "Skizofrenia" "Harga Diri Rendah", "Latihan Kemampuan positif", "Latihan Kemampuan positif + Harga Diri Rendah".

Artikel yang dipilih adalah artikel yang dipublikasikan sejak tahun 2015 sampai dengan 2020 yang dapat diakses fulltext dalam format pdf dan berbahasa Indonesia. Artikel penelitian yang terpublikasi melakukan penerapan latihan kemampuan positif akan dimasukkan dalam literature review. Analisis data dilakukan dengan cara mendiskusikan dan meringkas literature kemudian membandingkan beberapa literature dan selanjutnya dituangkan dalam pembahasan.

Untuk mereview sebuah literature bisa melakukannya dengan beberapa cara: 1 . Mencari kesamaan (Simmiliarity), 2. Mencari Ketidaksamaan (Contrast), 3. Memberikan pandangan (Criticize), 4. Membandingkan (Compare), 5. Meringkas (Summarize).

Berdasarkan Hasil Literatur Review dari 5 artikel menunjukkan bahwa latihan kemampuan positif sangat bervariasi. Latihan kemampuan positif dimaksud terdiri dari aktivitas merias diri, terapi menjahit, aktivitas mencuci, kegiatan menggambar dan kegiatan Plant Therapy. Secara signifikan menunjukkan semua latihan kemampuan positif dapat meningkatkan dan mempertahankan kemampuan yang masih dimiliki klien dan ditampilkan tabel 1. 


\begin{tabular}{|c|c|c|c|c|}
\hline No & Judul & Metode Penelitian & Subjek Penelitian & Hasil \\
\hline 1 & $\begin{array}{l}\text { Upaya Meningkatkan } \\
\text { Harga Diri Dengan } \\
\text { Kegiatan Positif Pada } \\
\text { Pasien Harga Diri } \\
\text { Rendah } \\
\text { (Meryana, 2017) }\end{array}$ & $\begin{array}{l}\text { Deskriptif dengan } \\
\text { pendekatan studi kasus, } \\
\text { yaitu dengan melakukan } \\
\text { asuhan keperawatan } \\
\text { pada klien harga diri } \\
\text { rendah mulai dari } \\
\text { pengkajian, intervensi, } \\
\text { implementasi, dan } \\
\text { evaluasi keperawatan }\end{array}$ & $\begin{array}{l}\text { 1 Orang dengan harga diri } \\
\text { rendah yang dirawat di } \\
\text { RSJD Arif Zainudin } \\
\text { Surakarta }\end{array}$ & $\begin{array}{l}\text { Masalah teratasi sebagian dan } \\
\text { intervensi harus dilanjutkan }\end{array}$ \\
\hline
\end{tabular}

2 Penerapan Kegiatan Metode yang digunakan 1 Orang Tn.J dengan Menjahit Pada Tn.J dengan studi kasus. masalah harga diri rendah Dengan Masalah Harga Diri Rendah

(Ita, 2019)
3 Upaya Aktivitas Merias Diri Untuk Meningkatkan Harga Diri Pada Pasien Harga Diri Rendah

(Dwi, 2019)

4 Terapi Kreasi Seni Menggambar

Terhadap

Kemampuan

Melakukan

Menggambar Bentuk pada Pasien Harga

Diri Rendah

(Mulyawan, 2018)

$5 \quad$ Plant Therapy Untuk Meningkatkan Harga Diri Rendah Pada Klien Harga Diri Rendah Di Panti Rehabilitasi Pengemis, Gelandangan dan Orang Terlantar
Desain penelitian yang digunakan adalah tipe studi kasus dengan pendekatan deskriptif yang bisa didapat melalui wawancara maupun observasi.

Quasi Experimental Pre-post without rendah control

Ceramah, Diskusi, Penghuni PR- PGOT Demonstrasi dan dengan harga diri rendah pelaksanaan kegiatan. yang sudah kooperatif

3 orang Nn.D, Ny.S yang mengalami Skizofrenia dengan gangguan konsep diri harga diri rendah.
Mendiskusikan SP 1 dengan mengidentifikasi aspek positif yang dimiliki, perawat menanyakan kemampuan apa saja yang Tn.J miliki, kemudian menjawab dengan ragu-ragu kemampuan yang dimiliki meliputi merapikan tempat tidur, menyapu, melipat baju dan menjahit. Pada saat diskusi terlihat tidak ada kontak mata, dilanjutkan dengan memilih/menentukan kemampuan yang akan dilatih. Tn.J memilih kegiatan yang masih bisa dilakukan yaitu menjahit.
Ada peningkatan kemampuan berhias atau bermake-up bermanfaat untuk meningkatkan harga diri pasien.

(Puji, 2019) 


\section{Pembahasan}

Harga diri rendah adalah perasaan negatif terhadap dirinya sendiri menyebabkan kehilangan rasa percaya diri, pesimis, dan tidak berharga di kehidupan (Dermawan,2013). Gangguan harga diri rendah akan terjadi jika kehilangan rasa kasih sayang, perlakuan orang lain yang mengancam dan hubungan interpersonal yang buruk. Harga diri akan meningkat bila diperhatikan/dicintai dan dihargai atau dibanggakan.

Menurut Herman (2011) menyatakan bahwa cara mengontrol harga diri rendah meliputi, mendiskusikan kemampuan dan aspek positif yang dimiliki pasien, membantu pasien menilai kemampuan yang masih dapat digunakan, membantu pasien memilih atau menetapkan kemampuan yang akan dilatih, melatih kemampuan yang sudah dipilih dan menyusun jadwal pelaksanaan kemampuan yang telah dilatih dalam rencana harian, melatih pasien melakukan kegiatan lain yang sesuai dengan kemampuan pasien.

Kemampuan positif merupakan kemampuan atau aspek positif yang dimiliki individu untuk mengidentifikasi kemampuan yang ada pada diri individu itu sendiri, sehingga klien dapat memilih kegiatan sesuai kemampuan yang dimilikinya. Dari kelima jurnal yang digunakan terdapat beberapa kesamaan diantaranya jurnal ke- 1,2,3,4,5 memiliki kesamaan pada sampel yang diambil yaitu pasien dengan masalah harga diri rendah, mayoritas intervensi penelitian diberikan oleh perawat. Kelima jurnal memiliki tujuan penelitian yang sama untuk meningkatkan rasa percaya diri pada klien harga diri rendah dengan cara latihan kemampuan positif, dan memiliki kesamaan dalam pokok bahasan yaitu samasama membahas tentang latihan kemampuan positif pada klien harga diri rendah.

Dari 5 artikel yang menjadi sampel penelitian ini 3 diantaranya menggunakan metode studi kasus, 1 yang lain menggunakan metode Quasi Experimental Pre-post without control dan 1 yang lain menggunakan metode ceramah dan diskusi. Studi kasus yaitu melakukan asuhan keperawatan pada klien harga diri rendah mulai dari pengkajian, intervensi, implementasi, dan evaluasi keperawatan. Sedangkan Quasi Experimental Pre-post without control peneliti memberikan perlakuan yang sama pada semua klien untuk diberikan intervensi.

Total jumlah responden yang digunakan dalam masing-masing penelitian berada pada rentang 1-33 orang. Dalam peningkatan rasa percaya diri pada klien dipengaruhi oleh beberapa jenis latihan kemampuan positif. Berbagai jenis latihan kemampuan positif yang mempengaruhi peningkatan rasa percaya diri pada klien adalah aktivitas merias diri, terapi menjahit, aktivitas mencuci, kegiatan menggambar dan kegiatan Plant Therapy. Intervensi pada latihan kemampuan positif terhadap peningkatan rasa percaya diri memiliki peluang yang besar untuk diterapkan para perawat di rumah sakit atau komunitas. 


\section{Kesimpulan}

Dari 5 jurnal penelitian yang di analisa memiliki judul dan abstrak yang relevan. Didapatkan bahwa dari 5 penelitian yang digunakan 3 diantaranya menggunakan metode studi kasus, 1 yang lain menggunakan metode Quasi Experimental Pre-post without control dan 1 yang lainnya menggunakan metode ceramah dan diskusi.

Berdasarkan penelitian- penelitian di atas menunjukkan bahwa latihan kemampuan positif sangat bervariasi. Latihan kemampuan positif dimaksud terdiri dari aktivitas merias diri, terapi menjahit, aktivitas mencuci, kegiatan menggambar dan kegiatan Plant Therapy. Secara signifikan semua latihan kemampuan positif dapat meningkatkan dan mempertahankan kemampuan yang masih dimiliki klien.

\section{Ucapan Terimakasih}

Penulis mengucapkan terima kasih kepada Direktur Akper Pemkab Purworejo dan Ketua Lembaga Penelitian dan Pengabdian Masyarakat yang telah memberikan dukungan dalam penyelesaian publikasi ini.

\section{Daftar Pustaka}

Amin Huda Nurarif, Hardhi Kusuma, (2016). Buku Asuhan Keperawatan Praktis Berdasarkan Penerapan Diagnose Jilid 1. Jogjakarta: Media Action.

Abdul Wakhid, Achir Yani S. Hamid, Novy Helena,(2015). Penerapan Terapi Latihan Ketrampilan Sosial Pada Klien Isolasi Sosial Dan Harga Diri Rendah Dengan Pendekatan Model Hubungan Interpersonal Peplaudi Rs Dr Marzoeki
Mahdi Bogor. Diakses 29 juni 2021 dari 103.97.100.145/index.php/JKJ/article/vi ew/911 jam 10.35.

Budiman, (2010). Jumlah Gangguan Jiwa. Tanggal 04 November 2019. Jam 16.45 WIB.

Dwi, dkk (2019). Upaya Aktivitas Merias Diri Untuk Meningkatkan Harga Diri Pada Pasien Harga Diri Rendah. Diakses 06 Februari 2020, dari http://repository.itspku.ac.id/ 141/. Jam 19.32 WIB

Ferdi, (2018). Gambaran Tingkat Emosi Keluarga Untuk Melakukan Perawatan Di Rumah Pada Pasien Gangguan Kejiwaan Di RSJD Atma Husada Mahakam Samarinda. Tanggal 03 November 2019. Jam 16.45 WIB.

Fitria, (2009). Model Perawat dalam praktek keperawatan jiwa. Jakarta: Penerbit Buku Kesehatan.

Garry Reynaldi, (2016). Upaya Peningkatan Aktualisasi Diri Pada Klien Dengan Harga Diri Rendah di RSJD Arif Zainudin Surakarta. Tanggal 04 November 2019. Jam 17.29 WIB.

Ita, (2019). Penerapan Kegiatan Menjahit Pada Tn.J Dengan Masalah Harga Diri Rendah. Diakses 02 Juni 2020, dari http://ejournal.akperkbn.ac.id lindex.php/jkkb/article/view/52

Keliat, (2009). Proses Keperawatan Jiwa. Jakarta: EGC.

Keliat, (2010). Keperawatan Kesehatan Jiwa Komunitas. Jakarta: EGC. Pengemis, Gelandangan dan Orang Terlantar. Diakses 06 Mei 2020, dari http://khidmah.stikesmp.ac.id /index.php/khidmah/article/vi ew/300. Diakses tanggal 29 juni $\underline{2020}$

Keliat, (2011). Keperawatan Kesehatan Jiwa 
Komunitas. Yogyakarta: EGC.

Kustiawan, Ridwan. 2015. Pengaruh Pendidikan Kesehatan Keluarga Terhadap Kemampuan Keluarga Merawat Klien HDR di Kota Tasikmalaya. Buletin Media InformasiVolume 1 No. 1 . http://ejurnal.poltekkestasikmalaya.a c.id/index.php/BMI/article/view/31.

Diakes pada tanggal 04 Juni 2020.

Meryana, (2017). Upaya Meningkatkan Harga Diri Dengan Kegiatan Positif Pada Pasien Harga Diri Rendah. Diakses 06 Februari 2020 dari http://eprints.ums.ac.id/52274/4/BAB $\% 202 \% 20$ SEBENARNYA.pdf. diakses tanggal 20 juni 2020

Muhith, A dan Nasir, (2016). Pendidikan Keperawatan Jiwa. Yogyakarta: CV Andi Offset.

Mulyawan M dan Marisca A, (2017). Terapi Kreasi Seni Menggambar Terhadap Kemampuan Melakukan Menggambar pada Pasien Harga Diri Rendah. Diakses 04 Juni 2020, dari

http://journals.stikim.ac.id/index.php/ jiiki/article/view/325

Puji, (2019). Plant Therapy Untuk Meningkatkan Harga Diri Rendah Pada Klien Harga Diri Rendah Di Panti Rehabilitasi

http://khidmah.ikestmp.ac.id/index.p hp/khidmah/article/view/300.

Diakses tanggal 29 juni 2020

Rosida, (2017). Asuhan Keperawatan Jiwa Pada Klien Skizofrenia Dengan Perubahan Konsep Diri : Harga Diri Rendah Kronik di Wilayah Puskesmas Gombong II. Tanggal 04 November 2019. Jam 17.24 WIB.

Riska, (2018). Asuhan Keperawatan Jiwa Pada Keluarga Denganharga Diri Rendah Kronis Diwilayah Kerjapuskesmas Nanggalo
Padang.http://pustaka.poltekkespdg.a c.id/repository/perpus-ilovepdfcompressed.pdf tanggal 26 juni 2020

Yosep, (2010). Buku Ajar Keperawatan Jiwa. Bandung: Refika Aditama.

Fusfita, (2017). Gambaran Status Mental Pasien Skizofrenia di Rumah Sakit Jiwa Daerah Soedjarwadi Klaten.http://eprints.ums.ac.id/id/eprint I50979 Tanggal 03November 2019. Jam 17.09 WIB. 